\title{
MARKET FORCES AND SEX DISCRIMINATION
}

\author{
Judith K. Hellerstein
}

David Neumark

Kenneth R. Troske

Working Paper 6321 
NBER WORKING PAPER SERIES

\title{
MARKET FORCES AND SEX DISCRIMINATION
}

\author{
Judith K. Hellerstein \\ David Neumark \\ Kenneth R. Troske
}

Working Paper 6321

http://www.nber.org/papers/w6321

\author{
NATIONAL BUREAU OF ECONOMIC RESEARCH \\ 1050 Massachusetts Avenue \\ Cambridge, MA 02138 \\ December 1997
}

We are grateful to Kim Bayard for outstanding research assistance, and to seminar participants at the University of Maryland, the University of Missouri, and the NBER Summer Institute for helpful comments. This research was supported by NSF grant SBR95-10876 to the NBER. Neumark's research with the data used in this paper was also supported by NIA grant K01-AG00589 to the NBER. Any opinions expressed are those of the authors and not those of the or the National Bureau of Economic Research.

(C) 1997 by Judith K. Hellerstein, David Neumark and Kenneth R. Troske. All rights reserved. Short sections of text, not to exceed two paragraphs, may be quoted without explicit permission provided that full credit, including $(\mathcal{O}$ notice, is given to the source. 
Market Forces and Sex Discrimination

Judith K. Hellerstein, David Neumark

and Kenneth R. Troske

NBER Working Paper No. 6321

December 1997

JEL Nos. J71, J16, J24

ABSTRACT

We report new evidence on the existence of sex discrimination in wages and whether competitive market forces act to reduce or eliminate discrimination. Specifically, we use plant- and firm-level data to examine the relationships between profitability, growth and ownership changes, product market power, and the sex composition of a plant's or firm's workforce. Our strongest finding is that among plants with high levels of product market power, those that employ relatively more women are more profitable. No such relationship exists for plants with apparently low levels of market power. This is consistent with sex discrimination in wages in the short run in markets where plants have product market power. We also examine evidence on the longer-run effects of market forces on discrimination, asking whether discriminatory employers with market power are punished over time through lower growth than non-discriminatory employers, or whether discriminatory employers are bought out by non-discriminators. We find little evidence that this occurs over a five-year period, as growth and ownership changes for plants with market power are generally not significantly related to the sex composition of a plant's workforce.

Judith K. Hellerstein

Department of Economics

3105 Tydings Hall

University of Maryland

College Park, MD 20742

and NBER

hellerst@econ.umd.edu

Kenneth R. Troske

Department of Economics

University of Missouri

Columbia, MO 65211
David Neumark

Department of Economics

Michigan State University

East Lansing, MI 48824

and NBER

dneumark@msu.edu 


\section{Introduction}

The residual wage gap between men and women has been documented and replicated in an extensive body of research. The interpretation of this gap, however, is controversial. Some view the residual wage gap as evidence of sex discrimination in wages, arguing that if a gap remains after controlling for variables measuring workers' productivity, it must reflect discrimination. This interpretation of the evidence comes directly from Becker's (1971) classic model of employer discrimination, in which discrimination is reflected in a gap between wages and marginal products. ${ }^{1}$ Others, citing the same model, focus on Becker's conclusion that under sufficiently competitive conditions discriminatory employers will fail to thrive, and will eventually be competed out of existence. Since the sex-wage differential has persisted, they conclude, it must reflect unobserved productivity differences rather than discrimination (e.g., Fuchs, 1988, Chapter 3; O'Neill, 1994). ${ }^{2}$ Given that the household- or individual-level data sets used to estimate unexplained or residual wage gaps between men and women contain only proxies for workers' productivity (such as schooling and experience), it is difficult to refute the argument that the residual wage gap reflects unobserved productivity differences. Thus, in our view, evidence on residual wage gaps at a point in time from such data sets cannot fully resolve the question of whether discrimination exists in labor markets. Furthermore, because we have no firm idea as to how quickly sources of the residual sex-wage gap other than discrimination might be changing, evidence on changes in the sex-wage gap over time may not be particularly informative regarding

${ }^{1}$ Neumark (1988) outlines the relationship between the Becker model and wage equation studies of discrimination.

${ }^{2}$ Becker carefully specifies the conditions under which this result holds, although in our view these conditions have been glossed over by those who insist that the Becker model implies that discrimination cannot persist. 
the role of competition in eliminating or reducing discrimination. ${ }^{3}$ Thus, such evidence also cannot decisively address the hypothesis that market forces tend to eliminate discrimination.

In this paper, we report new evidence on both of these issues: whether sex discrimination exists, and whether competitive market forces act to reduce or eliminate discrimination. The nature of the evidence is new in that we focus not on individuals' wages but on the other side of the market. Specifically, we use plant- and firm-level data to examine "short-run" (cross-sectional) profitability and longer-run growth and ownership changes, in relation to the sex composition of a plant's or firm's workforce. Furthermore, we explore how these relationships vary with the strength of competition in product markets.

We begin with a simple test for sex discrimination. In particular, if there is no market wage discrimination against women, then there should be no cross-sectional relationship between profitability and the sex composition of the workforce. Any sex difference in wages must reflect only observed or unobserved productivity differentials between men and women, and firms or plants that employ more women should earn no higher profits. We test this hypothesis by estimating the cross-sectional relationship between plant or firm profitability and the sex composition of the workforce, using a unique data set that matches workers to plants. A finding that plants or firms that employ relatively more women earn higher profits, in contrast, would be consistent with sex discrimination in the labor market.

Next, we explore whether competitive market forces undermine discrimination. We first look at a static test, asking whether-as the Becker model predicts-there appears to be a positive short-run relationship between profitability and the sex composition of the workforce only among

${ }^{3}$ Goldin (1990) provides evidence on the evolution of the sex-wage gap over the 20th century. O'Neill (1985) presents evidence of narrowing of this gap in the 1980s, but Blau, et al. (1997) report evidence that this narrowing may have halted in the 1990s. 
firms or plants with product market power, because among such plants or firms positive economic profits may be exploited to indulge the discriminatory tastes of some employers. ${ }^{4}$

The results on profitability can tell us whether, at a point in time, there appears to be sex discrimination, and whether this discrimination occurs where there is product market power. This evidence is arguably more decisive than that obtained from wage regressions with individual-level controls, because profitability, unlike wages, is a direct measure of performance. In addition, the results incorporating market power are informative about the role of competitive market forces. However, the existence at a point in time of higher profits in plants or firms employing more women (whether or not this occurs only where there is product market power) does not imply that market forces fail to reduce or eliminate discrimination, even in sectors where market power exists. Nothing in the Becker model rules out the existence in the short run of discriminating employers who drive a wedge between women's relative wages and relative marginal products, since nothing in the model rules out the existence of product market power over some period. Thus, a positive relationship between employment of women and profitability at a point in time does not contradict the dynamic implication of Becker's model that market forces may act over the longer run to undermine discrimination.

Market forces may reduce or eliminate discrimination through a number of channels. If the

\footnotetext{
${ }^{4} \mathrm{We}$ also look at evidence with respect to race and age. However, we concentrate on sex discrimination for two reasons. First, in earlier work with some of the data used in this paper we found other evidence consistent with fairly substantial sex discrimination (Hellerstein, et al., 1996), but little evidence of race discrimination. (In that paper, in contrast to the present paper, our estimation required specification of a structural production function. In addition, in the present paper we present new results on growth and survival, and more generally on competitive market forces and discrimination.) Second, a relationship between age of the workforce and profits can arise for non-discriminatory reasons; for example, if there are Lazear contracts (1979), then if firms are hit with negative demand shocks hiring may slow relative to the past, implying a disproportionate number of older workers as well as lower profits.
} 
product market is perfectly competitive, discriminating employers earn negative profits and are competed out of existence, whereas non-discriminating plants or firms that employ more women should have better long-run prospects and therefore expand relative to the market. Of course, in perfectly competitive markets discriminating employers may never be able to thrive in the first place, which is why we also examine how the relationship between profitability and the sex composition of the workforce varies with product market power. But the dynamic implications of Becker's model are not restricted to perfectly competitive markets. If there is product market power in the short run but entry is possible, discriminating employers may earn positive profits in the short run, but again should eventually be competed out of the market by new plants or firms. Finally, if there is market power with no entry, then the market for ownership of these plants and firms may ensure that eventually discriminating owners will be bought out by non-discriminating owners who will profitably alter the sex composition of the workforce in these newly-purchased plants, thereby bidding away discrimination; the conditions under which this should occur are discussed below. ${ }^{5}$

We use longitudinal data on the plants in our data set to test the dynamic implications of Becker's model. In particular, we ask whether non-discriminatory plants-those which, according to the cross-sectional evidence, employ more women and earn higher profits-grow faster or are less likely to undergo a change of ownership, compared with discriminatory plants that employ fewer women and earn lower profits. The combined static and dynamic evidence provides us with a better understanding of sex discrimination in labor markets and the role of competitive market forces in reducing or eliminating this discrimination than can be obtained from conventional wage

${ }^{5}$ In the case of oligopoly (as opposed to, e.g., natural monopoly), product market competition may also reduce the market share of discriminating employers, although this depends on the nature of competition among firms. 
equation approaches to discrimination, or from more convincing cross-sectional tests for discrimination (such as audit studies). ${ }^{6}$

\section{The Becker Model}

In this section we briefly review the Becker (1971) model. Consider a wage-taking firm with a production function $Y$ that uses two inputs: the labor of men, $M$, and the labor of women, $F$. If there is employer discrimination against women, so that employers have a distaste for hiring female workers, then employers do not maximize profits but rather maximize utility defined as

(1) $U(\pi, M, F)=P \cdot Y(M, F)-w_{M} M-w_{F} F-d \cdot F$,

where $d$ is the discrimination coefficient capturing an employer's distaste for female labor, $P$ is output price, and $w_{M}$ and $w_{F}$ are the market wages of men and women respectively. In this case utility maximization in the short run implies that

$$
\text { (2) } \quad M R P_{M}=w_{M}, M R P_{F}-d=w_{F} \text {. }
$$

That is, while the marginal revenue product of male labor is equal to the input price of male labor, it is the marginal revenue product of female labor discounted by the discrimination coefficient that is equated to the input price of female labor. The discrimination coefficient $d$ will lead the firm in the short run to hire fewer women than profit maximization would dictate; firms with weaker

${ }^{6}$ There is virtually no existing work attempting to draw conclusions regarding discrimination from data on profitability. One exception is Hersch (1991), who studies the effects of charges of EEO violations on the equity value of firms, finding that these charges reduce firm value. This evidence is indirect as regards testing for discrimination, although it is of independent interest. If EEO charges are targeting discriminatory employers in the sense of Becker's model, who hire relatively more men at higher wages, this evidence is difficult to understand, since profits at such firms should increase if discrimination is reduced. On the other hand, if these charges target within-firm wage differentials, it is plausible that settlement of the EEO charge will result in higher labor costs. At the same time, because of the legal costs of lawsuits, we might expect EEO charges to reduce the value of firms even in the absence of discrimination.

In addition, some of our earlier work indirectly uses data on profitability to study discrimination, by estimating wage and marginal productivity differentials across demographic groups (Hellerstein, et al., 1996; Hellerstein and Neumark, 1995). 
discriminatory tastes (smaller $d$ ) will tend to hire more women. ${ }^{7}$ Given the market wage differential determined by discriminatory tastes, firms that hire more women earn higher profits.

Becker then goes on to show that with this type of employer utility function, under some conditions market forces will cause discrimination to disappear in the long run. If product markets are perfectly competitive, then discrimination will disappear over time through competition in product markets if there are sufficient potential employers with non-discriminatory tastes. If product markets are not perfectly competitive but some entry is possible, then discrimination will be competed away if there are non-decreasing returns to scale and at least one potential employer has non-discriminatory tastes. In the case of total barriers to entry in product markets, even with decreasing returns to scale, if businesses are transferable and there is a potential nondiscriminating employer, discrimination may disappear through competition in the market for firms. Finally, Becker (1971, p. 44) notes that if employers' tastes are nepotistic rather than discriminatory, then the "discriminatory" wage gap will not be eliminated by competition in the market for firms. ${ }^{8}$

\section{Data}

The data used in this study come primarily from the Worker-Establishment Characteristics Database (WECD) and the Longitudinal Research Datafile (LRD). The WECD is a cross-sectional data set containing manufacturing workers' responses to the 1990 Decennial Census long form,

${ }^{7}$ Neumark (1988) considers alternative functional form specifications of the distaste for female labor that generate higher proportions of female workers for employers with less discriminatory tastes, whereas the constant $d$ in the Becker model tends to generate complete sex segregation across employers, except for the subset for whom $d$ exactly offsets the market wage differential between men and women.

${ }^{8}$ Goldberg (1982) provides a more formal discussion of the conditions under which discrimination is or is not competed away in the long run, whether in the product market or the market for firms, depending on whether employers' tastes are discriminatory or nepotistic. 
along with a link to establishment data in the LRD. The LRD is a panel data set consisting of establishment responses to the Census of Manufactures (CM) and the Annual Survey of Manufactures (ASM). The construction of these two data sets and the information contained in each will be discussed in turn. ${ }^{9}$

The WECD was constructed by first matching manufacturing worker records from the 1990 Sample Detail File (SDF) to establishment records in the 1990 Standard Statistical Establishment List (SSEL). The 1990 SDF consists of all household responses to the 1990 Decennial Census long form. The SDF contains the standard demographic information for workers collected on the long form of the Census, along with detailed location information and a three-digit census industry code for each respondent's place of work. The SSEL contains a complete list of all establishments in the U.S. in a given year and is used by the Census Bureau in administering its various economic censuses and surveys. The SSEL contains detailed location information and a four-digit SIC code for each establishment along with a unique establishment identifier that is common to other Census Bureau economic surveys and censuses.

Workers and establishments were matched using the detailed location and industry information available in both data sets. ${ }^{10}$ The first step in the matching process was to keep only manufacturing establishments that were unique to an industry-location cell. Next, all workers indicating that they work in the same industry-location cell as a retained establishment were linked

\footnotetext{
${ }^{9}$ The discussion here is brief. For a more detailed discussion of these data sets see Troske (forthcoming) and McGuckin and Pascoe (1988).

${ }^{10}$ For establishments in urban areas (primarily MSAs) a plant's location is coded at the block level. For establishments in rural areas a plant's location is coded at the place level. A place is either an incorporated governmental unit, or an area with significant population concentration that is not incorporated but that has characteristics similar to incorporated places. For a more complete description of geographic codes see "1992 Census of Population and Housing-Guide Part A. Text" (U.S. Bureau of the Census, 1992).
} 
to the establishment. Then all matches based on imputed data were dropped. Finally, the establishment's unique identifier was appended to the worker records. The identifier enables the worker data to be linked to the employer data in the LRD.

The second data set used in the analysis is the LRD. The LRD consists of every CM since $1963(1963,1967,1972,1977,1982,1987)$ as well as the $1973-1993$ ASMs. ${ }^{11}$ To construct the data set used in this paper, we link the worker data (based on the SDF and the SSEL) to the LRD using each establishment's identifier, creating the WECD. Since much of the labor market information in the Decennial Census refers to 1989, we link the worker records to establishments in the LRD in 1989 for our main cross-sectional analysis. To minimize the effects of outliers and reporting problems, we select workers who report working more than 30 weeks in the previous year and usually working more than 30 hours a week. ${ }^{12}$ To help ensure that we have a representative sample of workers in a plant, we only keep plants with at least three workers matched to the plant. ${ }^{13}$ From the worker records comes worker information such as age, education, sex, race, and occupation of workers in each plant. From the LRD comes employer information such as total employment in both the plant and the firm, total capital stock (book value) and output of the plant, the age of the plant, and the ownership structure.

In the matched data set, the worker data are used to construct the percent female, as well as

\footnotetext{
${ }^{11}$ Each CM is a complete census of all manufacturing establishments in a given year. Each ASM is a probability sample of establishments, surveyed over a five-year period. A new ASM sample is drawn two years after a census, with the probability of an establishment being included in the ASM increasing with its total employment in the previous CM. Establishments with more than 250 employees in the previous CM are in the ASM with certainty.

${ }^{12}$ The 1990 Decennial Census asks workers to report the address of the establishment where they worked in the previous week. Keeping workers that usually work more than 30 hours a week and who worked more than 30 weeks in the previous year increases the probability that the worker was employed at the same establishment throughout 1989 (Troske, forthcoming).

${ }^{13}$ This is not very restrictive. The average number of workers matched to a plant is around 30.
} 
the percentage of the workforce in each of a number of other categories (age, education, race, marital status, and occupation). The plant-level data are used to construct a number of controls for plant-level characteristics that may be related to profitability and growth, such as plant age, size, and industry. Finally, we define two measures of performance that we use as proxies for profitability. The first is operating income (sales - inventory accumulation - labor costs - material costs) divided by inventory-adjusted sales (i.e., current year sales plus the change in inventories). The second also subtracts out from the numerator purchased business services or overhead costs (such as purchased electricity, legal services, advertising, and repairs)..$^{14,15}$

The one obvious omission from this performance measure is that the numerator does not subtract off the costs of capital flow expenditures. In CM years, the Census Bureau collects detailed data on the book value of capital of each plant, but there is no straightforward method to transform this book value measure into a capital flow measure, and there is no straightforward way to recover the rental rate of capital. ${ }^{16}$ Instead, in our empirical work we control for the ratio of

${ }^{14}$ The firm performance measures used as proxies for profitability are essentially price costmargins (see, for example, Domowitz, et al., 1986). We note, however, that price-cost margins are sometimes used as measures of market power. If plants or firms have long-run market power (due to barriers to entry and non-transferability of firms) and discriminate against women, then over the long-run market competition will not eliminate discrimination, and there will be a persistent negative relationship between the price-cost margin and the percent female in the workforce. Below, however, we find the opposite-a persistent positive relationship between profitability and the percent female. Therefore, if anything, a direct causal link from market power to discrimination should be weakening our results.

${ }^{15}$ Overhead costs are only collected in CM years, so the overhead costs we use are from 1987. In addition, the book value of capital is only collected in CM years and we therefore use 1987 capital data. Because not all plants in the 1989 ASM can be linked back to the $1987 \mathrm{CM}$, we lose some observations as a result of this linkage. We experimented with the full sample of observations from 1989, using the profitability measure that does not include overhead costs and omitting variables involving capital; the results were very similar to those obtained for the restricted sample for which we have data in the $1987 \mathrm{CM}$.

${ }^{16} \mathrm{An}$ ambitious effort to convert book values of capital into capital flows and rental rates is described in Caballero, et al. (1995). 
book value of capital to shipments on the right hand side of the regressions when appropriate. This provides some control for the variation across plants in capital expenditures.

Since the Becker model of employer discrimination is based on the actions of owners, focusing solely on plants could be somewhat misleading if decision making is done at the firm level. The Census Bureau focuses on plants in its data collection, but in CM years we can link together all plants that belong to the same parent firm, and we can obtain information on costs incurred and on employment at the non-production facilities of these firms. We therefore also construct a firm-level data set paralleling our 1989 plant-level data set, by matching workers in the WECD to plants in the $1987 \mathrm{CM}$, and then combining data on all establishments belonging to the same firm. Because information on the demographic characteristics of the workforces of these firms comes from the Census of Population, we are forced to assume that the demographic composition of each firm's workforce was the same in 1987. We use these firm-level data to estimate cross-sectional profitability regressions for 1987 , exploring the robustness of some of the results we obtain from the richer plant-level data.

Because of the difficulties involved in defining and tracking firms over time, in our analysis of the dynamic implications of the Becker model we focus only on plants. The WECD provides data on plant profitability and workforce characteristics only at a point in time, so we cannot follow the evolution of workforce characteristics over time. We can, however, study future growth by matching plants in the WECD to the 1990 and 1995 ASMs, defining growth both in terms of employment growth and shipments growth from 1990 to 1995 . We also look at the issue of plant ownership changes by identifying the plants in the 1990 ASM that have a different owner in the 1995 ASM. Because the Census Bureau drew a new ASM sample as of 1994, there are plants in the 1989 ASM that are not in the 1995 ASM simply because they were not selected to be 
in the more recent sample; these plants are omitted from the dynamic analysis. Finally, we note that the period 1990-1995 may represent a window that is short relative to the long run that is the focus of Becker's model, but 1995 is the most recent year of data available. ${ }^{17}$

Table 1 presents descriptive statistics for these data. In column (1), we report summary statistics for the full sample of 3089 plants in the 1989 ASM that appear in the WECD. In column (2), we report statistics from the sample of 2578 firms that we construct by linking plants together with units from the same firm, using the $1987 \mathrm{CM}$. In column (3), we again report statistics on data from plants in 1989 , but this time only for the sub-sample of 2634 plants for which we also have data in the 1995 ASM. The most important thing to note from this table is that differences across the columns are minor. In particular, the similarities of the results in columns (1) and (3) suggest that our analysis of plant growth and ownership change between 1990 and 1995 does not suffer from sample selection due to fact that the ASM sample changed over the period in question.

Finally, we note that the percent female varies widely across plants, and the data are not characterized by complete or near-complete segregation. In particular, in 49 percent of the plants 0-25 percent of the workers are female (in 14 percent $0-5$ percent are female), in 32 percent of the plants 25-50 percent are female, in 15 percent of the plants 50-75 percent are female, and in 5 percent of the plants $75-100$ percent are female.

${ }^{17}$ The 1990-1995 period included a recession and the beginning of a recovery. If otherwise faster-growing plants or firms are hurt more by recessions and take longer to recover than otherwise slower-growing plants or firms, then it might be difficult to detect the positive effect on growth of some other variable (such as the percent female among a plant's workforce). But previously struggling plants and firms generally suffer more during recessions than healthy ones, and presumably take longer to recover from such downturns. In an earlier version of this paper the latest ASM we had available was for 1993, when any effects of the recession should have been more severe. However, the results were very similar to those using the 1995 data, suggesting that this problem is minor. 


\section{Empirical Approach and Results}

We first test for a positive relationship between profits and the percent female by estimating regressions of plant- or firm-level profitability measures on plant or firm characteristics and demographic controls including the percent female. In particular, we attempt to control for other factors that are likely to be associated with profitability, such as age, industry, and measures of market power. As discussed in Section III, we also control for the ratio of capital (book value) to shipments, since the profit rate measure we use does not account for capital expenditures. In the idealized case in which the data reflect perfect competition in the long run, our measures of profitability would be unrelated to all of these variables except the capital/shipments variable. ${ }^{18}$ On the other hand, if some employers are discriminating against women, plants or firms that employ more women should earn higher profits. This relationship may be particularly strong among plants or firms that have product market power, for which competitive market forces may play less of a role in punishing discriminating employers, at least in the short run.

Our second set of estimates turns to the question of the longer-run prospects of plants that appear to discriminate by hiring fewer women, compared with those that do not. For the subsample of plants that do not change ownership between 1990 and 1995 (and for which we have data from both years), we estimate models of growth in output or employment, as functions of the same plant and workforce characteristics used in the profitability regressions. We also take all the plants for which we have data in 1990 and 1995 and estimate ownership-change models using the

${ }^{18}$ This is true only insofar as our profit measures capture economic profits, rather than accounting profits. As long as divergences between accounting and economic profits are unrelated to plant or firm characteristics, this prediction should still hold. 
same covariates. ${ }^{19,20}$

\section{Profitability and the Percent Female}

Table 2 begins the analysis of the cross-sectional relationship between profitability and the percent female, reporting OLS estimates of regressions for our two profit measures for plants in the WECD. In columns (1) and (2), we estimate regressions using the full sample of plants for which we have data in 1989. In column (3), we report results using the sub-sample of plants in 1989 for which we also have data in 1995 . The results indicate that, whether or not we subtract overhead costs from income, and no matter which sample of plants we use, the percent female in a plant's workforce is significantly positively related to profitability. For example, the point estimate in column (2) indicates that a ten percentage point increase in female employment raises the profit rate by .98 percentage point. Using the mean from the first row of Table 1 , this represents a 4.6 percent increase in the profit rate. This estimate seems somewhat high, although of the right order of magnitude, in light of existing estimates of wage discrimination by sex. For example, suppose that the entire wage differential between men and women in these data (approximately 30 percent) reflects discrimination, which is an extreme estimate. Suppose further that output is constant, and that average product equals marginal product. Then if labor costs represent 75 percent of total costs, a ten percentage point increase in female employment (coupled with a similar absolute decline in male employment) entails an increase in operating income or profits and hence an

${ }^{19}$ Plants that fail during this period are included in the sample; they are assigned shipments and employment growth (measured as the proportional change) of -1 , and no ownership change.

${ }^{20}$ In our reported results, we do not include plants that changed ownership in the growth regressions, because the mechanism by which discrimination is potentially competed away for these plants is through the market for plants, not the product market. Thus, a change in ownership should obviate the need for "punishment" by the product market. Results including plants that changed ownership were consistent with this; when these plants were included the relationship between percent female and growth was weaker. 
increase in the profit rate of 2.3 percent. $^{21}$

Aside from the findings for the percent female, the results in the first three columns of Table 2 provide little evidence of other variables that are significantly related to profitability. In particular, the only other demographic characteristic of workers that is consistently significantly related to profitability (at the five- or ten-percent level) is the percent of workers aged 55 and over, which we suspect reflects shocks to plants' profitability; for example, a negative shock would reduce hiring and lead to an older work force, more so if there are seniority rules regarding layoffs. ${ }^{22}$ The absence of any positive relationship between profitability and the percent black in the workforce is consistent with no discrimination against blacks. Of the variables representing the proportion of workers in different occupations, only the percent of the workforce in sales is significantly related to profitability (although this result is not robust across alternative estimations). The absence of any systematic relationship between profitability and so many of the demographic characteristics suggests that there are not large problems with unobservable characteristics of workers biasing our results for the percent female, since we would expect many unobservables that were correlated with the percent female to also be correlated with other worker characteristics.

To help control for other differences across plants in our profitability measure, we include in the profitability regressions in Table 2 two-digit industry dummy variables as well as the capital/shipments ratio of the plant in 1987 . Using 1987 data to construct the capital/shipments variable should eliminate endogeneity bias. The estimated coefficient of this variable, while

\footnotetext{
${ }^{21}$ The latter effect on the profit rate could be a bit smaller still if plants respond to lower marginal cost by increasing output, thus lowering the price.

${ }^{22}$ The negative estimate for older workers appears not to reflect plant life-cycle effects. As Table 2 shows, we have included detailed plant age dummy variables.
} 
statistically insignificant, is negative. This may seem surprising at first, but the capital measure we have is book value of capital, which is a non-depreciated measure of past capital investments made by the plant. To the extent that firms with higher book values of capital also have older capital whose real value is lower than its book value (due to depreciation), the negative coefficient on the capital/shipments variable is not surprising. ${ }^{23}$

Finally, we also include in the first three columns of Table 2 a measure of the market power of a plant in its output market. To do this, we use data from the $1987 \mathrm{CM}$ to calculate the share of shipments produced in 1987 by a plant, relative to the total shipments of all plants in 1987 in the same four-digit industry. This variable, obviously, is a plant-specific measure, in contrast to other market power measures such as four-firm concentration ratios that are defined at the industry level. Incorporating a market power measure that varies across plants within an industry is particularly important here, given that we want to investigate profitability differences across plants while controlling for industry differences. In particular, in the regressions we estimate we already include two-digit industry dummies and, in later tables, three- and four-digit industry dummies. We can only construct this output share variable using 1987 data because it is only in CM years that we have a measure of total industry shipments. In addition, using 1987 data mitigates endogeneity bias in the profitability regressions. We include in the first three columns of Table 2 quartile dummy variables defining a plant's location in this industry output share distribution. The estimated coefficients of the quartile dummy variables are monotonically increasing across the quartiles and are highly significant, indicating that plants with higher output shares earn higher

\footnotetext{
${ }^{23}$ Another reason for the estimated negative coefficient on the ratio of book value of capital to shipments may be because the book value of capital is positively correlated with wages (Troske, 1997). We also experimented with including the book value of capital to shipments ratio nonlinearly into the regression; the results were not qualitatively affected.
} 
profit rates than plants with lower shares of output relative to their four-digit industries, as we would expect if output share is a good proxy for market power.

The similarity of the results in columns (2) and (3), which differ only in the sample of plants used in estimating the regressions, again suggests that we do not have a sample selection problem resulting from the selection of a new sample of plants in 1994 that is used for the dynamic analysis that follows. In the rest of our cross-section results using 1989 data, we therefore only report results for the full sample of 3089 plants, the sample represented in the first two columns of Table 2.

As we mentioned above, any model of employer behavior should be tested using data at the level at which the employer makes decisions. In the case of employer discrimination, this might imply testing for discrimination at the level of the firm, if discrimination stems from the preferences and behavior of employers (or managers) at the firm-level rather than at the plantlevel. In column (4), we present results for the sample of firms (rather than plants) that we constructed by aggregating together plants in the $1987 \mathrm{CM}$ that belong to the same firm. Because firms produce in a variety of four-digit industries, we cannot construct a firm-level market power measure analogous to the output share dummy variables we used in the plant-level regressions. We therefore report results using a specification that excludes market power measures. Nonetheless, the point estimates of the coefficients of variables for which we can construct firmlevel data are quite similar to the plant-level results (and are also similar to plant-level results from a regression excluding the output share dummy variables, which we do not report). In particular, the coefficient on percent female is .088 with a standard error of .014 , which translates into a 3.7 percent increase in a firm's profit rate from a ten percentage point increase in female workers in the firm. The similarity of the plant-level and firm-level results suggests that examining plant- 
level data is not biasing our results.

The results in Table 2 include controls for two-digit industries. However, our results may be biased if there is a lot of heterogeneity in what is produced by plants in the same two-digit industry. In particular, if there are differences in unobserved characteristics across plants within two-digit industries that are correlated with the percent female in the plant (for example, differences in technology), the coefficient estimates on percent female will be biased. One way to examine whether there is evidence that this is occurring is to control for finer levels of industry disaggregation. In Table 3, we replicate the profitability regressions with three- and four-digit industry controls. The coefficient on percent female using three-digit controls in column (1) is .072 , and while still significant with a standard error of .020 , is slightly smaller than the estimate we obtain using two-digit industry controls in the regression. The coefficient on percent female using four-digit controls, as reported in column (2), is still smaller, with an estimated coefficient of .046; however, it is still statistically significant. Nonetheless, this does suggest that the regressions in Table 2 may be misspecified. Indeed, as we explain in the following section, there are theoretical reasons to think that the specifications in Tables 2 and 3 are not fully adequate for testing the implications of Becker's model.

\section{Market Forces and Discrimination, A Cross-Sectional Test}

As discussed earlier, the Becker model makes some rich predictions regarding how market power can inhibit the influence of competitive forces in eliminating discrimination (although competition in the market for firms may still exert such influence). The argument is that plants or firms with product market power are more likely to be able to engage in discriminatory practices, while those with less market power will be unable to do so, since competition and free entry quickly punish discriminators. Thus, the Becker model predicts that for plants or firms with 
considerable product market power there will be a positive relationship between employment of women and profitability, whereas for plants or firms with little market power, the relationship will be non-existent or at least weaker. ${ }^{24}$ This, in turn, suggests that the specifications used in Tables 2 and 3 , with the percent female and the output share dummy variables included linearly, may not adequately capture the richness of the relationship between the sex composition of the workforce and profitability, if this relationship in fact reflects discrimination.

We first test this prediction in column (1) of Table 4, where we report results from plant profitability regressions using specifications like those in Table 2 (with two-digit industry controls), but adding interactions between the output share dummy variables and the percent female in the plant. ${ }^{25}$ The results are not dramatic, but rather they hint at a richer relationship between profitability and percent female than is indicated by the specification with a simple linear term for the percent female. The estimated coefficient on the linear term for the percent female (.088) is only slightly smaller than in Table 2 , and the p-value of the joint test of the restriction of equal effects of the percent female across output share quartiles is .287 . Nonetheless, while none of the percent female interactions is statistically significant, the point estimate of the fourth quartile interaction (.059) is positive and rather large relative to the linear coefficient estimate.

It is again important to determine whether the level of industry disaggregation we use is affecting the results. If the industry controls are not fine enough, the output share of plants within two-digit industries may be a proxy for differences across industries defined at a more disaggregated level, particularly as output share is a measure of relative size. For example, if

\footnotetext{
${ }^{24}$ The relationship between market power and discrimination is also explored in Ashenfelter and Hannan (1986).

${ }^{25}$ We use the profitability measure subtracting out overhead costs, although using the overhead cost data has no substantive impact on the results.
} 
output share is correlated with technological differences across industries defined more finely than at the two-digit level, and if these technological differences across plants are related to the sex composition of the workforce, this could lead to spurious interactions between the percent female and output share. In columns (2) and (3), therefore, we estimate the regressions incorporating interactions between output share and percent female, but using three- and four-digit industry controls, respectively.

In column (2), the specification with three-digit industry controls, the linear term on percent female is .052 , which is smaller than in column (1), and smaller than in the specification in the previous table with three-digit controls but with no output share interactions (Table 3, column (1)). Moreover, it is not quite statistically significant at the ten-percent level. The coefficient on the second quartile interaction is again negative and statistically insignificant, while the third and fourth quartile interactions are both larger than in column (1) of this table. In particular, the coefficient on the fourth quartile output share interaction is .109 and is significant, with a standard error of .045 . The p-value for the test of the restriction of equal effects across the four quartiles is .004 , strongly rejecting the inclusion of only a linear term for percent female in the regression. In column (3), we present parallel results using four-digit industry controls. Here, the linear coefficient on percent female, which is .024 , is smaller yet relative to the first two columns of the table, and is statistically insignificant. The second quartile interaction continues to be negative and statistically insignificant, but its point estimate of -.053 is very similar to its counterpart in the regression with three-digit industry controls. The most important results in column (3) are that the third and fourth quartile interactions are larger than those at the three-digit level (.062 and .136, respectively), and the fourth quartile interaction is strongly significant; its standard error is 050 . The equality of the effect of percent female across quartiles is again strongly rejected with a p- 
value of .001 . Therefore, the results from the first three columns of Table 4 suggest that, if anything, controlling for finer levels of industry disaggregation points more strongly to a significant nonlinear relationship between profitability and percent female that is related to the market power of the plant. While the results indicate that there is no systematic relationship between profitability and the percent female for plants with small output share, there is strong evidence, particularly at finer levels of industry disaggregation, of a strongly significant positive relationship between profitability and the percent female for plants with output shares in the top quartile of the output share distribution. Using the same calculation as before, for plants with the most market power the estimated coefficients in column (3) imply that a ten-percent increase in the percent female raises the profit rate by 1.60 percentage points $(10 \times\{.024+.136\})$, a percentage increase of 5.9 at the mean for this subset of plants. As for the simpler specification discussed earlier, this estimate appears somewhat high but not necessarily in an implausible range.

This positive relationship between percent female and profitability among plants with high output share is consistent with the predictions of the Becker model relating discrimination to market power. ${ }^{26}$ In plants that operate in a competitive output market, there is no performance advantage to hiring women, since discriminatory employers are unable to indulge their tastes for discrimination. But in (typically larger) plants where there is market power and where plants can discriminate if they wish, at least in the short run, those that do not discriminate and hire more women-who cost less-achieve better performance.

We conduct one other robustness check in Table 4. To the extent that the percent female

\footnotetext{
${ }^{26}$ These results are also consistent with tabulations from the 1940 Census reported by Becker, indicating that relative to firms operating in competitive industries, firms operating in monopolistic industries appear to engage in discriminatory behavior (1971, Table 2, p. 48); Becker's results, however, refer to hiring of non-whites.
} 
variable may be a proxy for other unobservable characteristics of the plant (including its workforce) that may affect profitability differently for plants with different levels of market power, it is reasonable to think that other demographic characteristics of the plant might also be proxies for such unobservables. This suggests that we should include in the regression a full set of interactions between the output share quartile dummy variables and all the demographic characteristics of workers in a plant, and verify whether the results for the percent female hold up. We do this in columns (4)-(6) of Table 4, again using different levels of industry controls across the columns. ${ }^{27}$ The first thing to note in each of these columns is that the coefficients on the third and fourth quartile interactions between output share and the percent female tend, if anything, to be slightly larger than they are in the first three columns. Second, at the bottom of the columns we report some results for the interactions of the output share quartiles with the other demographic characteristics; of all the interactions estimated, only one interaction with black and three interactions with age are significant at the ten-percent level, and only the age interactions are significant at the five-percent level. While these findings may suggest that there are reasons other than discrimination why worker characteristics are related to profitability, the fact that so few of these interactions are significant, and the fact that the percent female results persist, suggest to us that the results for the percent female are not being driven primarily by unobservables.

To summarize, the overall picture that emerges from Table 4 is that while there is no clear evidence of a relationship between profitability and the percent female for plants falling into the bottom 75 percent of the output share distribution, there is strong evidence of a positive and significant relationship between profitability and a more female workforce for plants with

\footnotetext{
${ }^{27}$ Note that in these specifications, because the output share quartile dummy variables are interacted with many variables, the estimated coefficients of the quartile dummy variables are not comparable to those in columns (1)-(3).
} 
considerable market power. We interpret this evidence as being most consistent with Becker's model of employer taste discrimination, in which, in the short run at least, plants that have market power (and only such plants) are able to indulge their discriminatory tastes if they wish, but forfeit profits as a result.

It is worth discussing in more detail and in the context of our cross-sectional results the market forces in Becker's model relating market power to discrimination. If wages are set competitively ${ }^{28}$ plants or firms that do not discriminate will hire men and women until the ratio of marginal revenue products between men and women is equal to the ratio of market wages. This is true regardless of whether the plant has product market power. In plants with technologies where men and women are perfect substitutes in production, the ratio of marginal revenue products is determined exogenously by the technology, and competition in the labor market will work to equate the ratios of marginal revenue products and wages. ${ }^{29}$ In that case, non-discriminatory employers will be indifferent between hiring men and women. If men and women are not perfect substitutes, the ratio of relative marginal products will be a function of the sex mix of the plant's workforce, and will therefore be a decision variable for the plant. Once again, however, competition in the labor market will determine the relative wages of men and women.

We interpret our cross-sectional results as suggesting that among the set of plants with product market power-which are typically larger plants-some plants exploit the supra-competitive

${ }^{28}$ The Becker model presumes that wages are set competitively and that there is therefore one market wage differential between men and women. Our data are consistent with this; when we estimate individual-level human capital regressions for the workers in these data, the estimated coefficient of the female dummy variable remains large when plant fixed effects are included in the regression (Hellerstein et al., 1996).

${ }^{29}$ This is the case discussed in detail in our previous paper (Hellerstein, et al., 1996), where the we use a production function that, in its simplified version, can be thought of as $Y(M+\phi F)$, where $\phi$ is the ratio of the marginal product of female labor to male labor. 
profits stemming from their product market power to indulge in discriminatory behavior against women. The fact that the wages of women are lower than the wages of men among plants with less market power, coupled with the fact that profitability is unrelated to the percent female in this more-competitive sector, means that women's productivity in the more-competitive sector must be correspondingly lower than men's productivity (for evidence, see Hellerstein, et al., 1996).

Similarly, the positive relationship between profitability and the percent female among plants with more market power implies that, relative to wages, women's productivity is higher in this lesscompetitive sector, possibly because of technological differences between the sectors (the perfect substitutes case), or because women are under-employed (in the imperfect substitutes case) in this sector. As long as plants in the less-competitive sector compete for workers with plants in the more-competitive sector, and as long as the latter sector is large enough, the market wage ratio between men and women will be determined in the more-competitive sector and will be equal to the relative marginal products of men and women in the more-competitive sector. Then, although there is discrimination against women by some employers in the less-competitive sector, women have no incentive to switch sectors. This equilibrium will persist unless or until competitive forces in the product market or in the market for firms begin to work and eventually bid up the wages of women in the less-competitive sector. The question then is whether, and how quickly, the competitive process works to undermine discrimination. We turn to evidence on this question in the next section.

\section{Market Forces and Discrimination, Dynamic Tests}

The preceding cross-sectional results suggest that plants or firms can indulge their discriminatory tastes only when they enjoy product market power. Nonetheless, market forces may reduce or eliminate discrimination as the more profitable plants or firms among those with 
market power grow relative to the less profitable ones, or as discriminating employers are bought out by non-discriminating employers. Obviously, if the effect of market forces is to reduce or eliminate discrimination over time, these forces can only act upon plants that have product market power in the first place and that use this market power to indulge discriminatory tastes. Since the results from the cross-sectional analysis show a relationship between profitability and the percent female that is robust only for plants in the fourth quartile of our market power measure, we restrict our focus in the analysis of growth and ownership change to those plants in this top quartile. Specifically, for plants in the top quartile of the output share distribution, we estimate regressions for growth of both employment and shipments, and probits for ownership change, as functions of, among other things, the percent female in a plant's workforce.

In Table 5 we examine whether discrimination is eliminated through competition in the product market by asking whether plants that initially employ more women and earn higher profits grow faster than otherwise similar plants. We examine two different measures of changes in performance over time: growth in employment and growth in shipments, both from 1990 to 1995. We look only at plants that do not change ownership over this period, as this is the sample of plants for which Becker's model predicts a clear relationship between shorter-run discrimination and longer-run growth.

In column (1) of Table 5, the dependent variable is the proportional change in shipments from 1990 to 1995 . We begin with a specification for the right-hand-side variables that parallels the first profitability regressions, using the same covariates as in the cross-sectional specifications in Table 2, including two-digit industry controls. The only exception is that we do not include as a regressor the capital/shipments ratio, since the dependent variable no longer suffers from a missing return to capital measure. The estimated coefficient on the percent female is negative at -.095 and 
is statistically insignificant with a standard error of .143 . The point estimate of the effect of the percent female in column (2), where the dependent variable is the percent change in employment, is similar, at -.120 with a standard error of $: 112 .^{30}$

In columns (3) and (4) we redo the analysis using three-digit industry controls, and in columns (5) and (6) we use four-digit controls. At the three-digit level in column (3), the point estimate on the relationship between the percent female and shipments growth is -.085 , which is slightly smaller than what it was at the two-digit level, and it has a slightly higher standard error. The point estimate falls even further, to -.036 , when we use four-digit industry controls in column (5), with a standard error of .218 . The employment growth results for percent female actually become positive as we disaggregate industries, with point estimates of .003 at the three-digit level and .027 at the four-digit level, but these coefficients are small and never close to being statistically significant. There is therefore no evidence that sex discrimination in wages, if it exists initially (as we concluded from our cross-sectional analysis), is reduced or eliminated by market forces that cause non-discriminatory plants to expand relative to discriminatory plants. ${ }^{31}$

${ }^{30}$ The only significant coefficients in column (1) are for the percent black and the percent aged 35-54 and 55+, all of which are negative. The result for percent black is not consistent across different levels of industry disaggregation, and, in particular, becomes insignificant at the fourdigit level. The result for older workers is fairly robust across levels of industry disaggregation, although its magnitude is smaller when employment growth is the dependent variable. As mentioned earlier, we interpret such results as reflecting plant-specific shocks.

${ }^{31} \mathrm{We}$ also examined the relationships between growth of both shipments and employment and the percent female for other quartiles of the capital stock and output share distributions. Given that we found no significant cross-sectional relationship between the percent female and profitability for plants in these quartiles in the cross-section, we would not have expected to find such a relationship in the growth results if the relationship between growth and the percent female is being driven by market forces affecting discrimination. Indeed, the results from the other quartiles show no relationship between the percent female and growth, with the estimated coefficients small and insignificant. In other words, the difference-in-difference estimate of the effect of the percent female on growth, using plants with considerable market power as the treatment group and the remaining plants as the control group, is zero.

Finally, we reestimated the growth regressions including lagged growth from 1982 to 
In Table 6 we analyze the effect of having a more female workforce in the base year on the probability of changing ownership between 1990 and 1995, again for plants in the top quartile of the output share distribution. Becker's model predicts that in the case of discriminatory tastes on the part of employers (as opposed to nepotistic tastes), plants with market power and with discriminating owners who hire too few women will tend to be bought out by non-discriminating owners. We test whether the data are consistent with this prediction of the model by estimating probits in which the dependent variable is one if the plant changed ownership and zero otherwise. The right-hand-side variable specifications are exactly the same as those in Table 5 and we again report results using two-, three-, and four-digit industry controls. The table reports "partial derivatives" of the outcome with respect to the regressors. No matter how finely we disaggregate industry, the point estimates of the effect of the percent female are negative, consistent with plants employing fewer women being more likely to change ownership, as predicted by Becker's model. However, there is no evidence of a statistically significant relationship between the percent female and ownership change. In fact, there are virtually no significant coefficient estimates anywhere in Table 6. The magnitude of the coefficient estimate on the percent female gets more negative across the columns, as the level of industry disaggregation becomes finer and finer, but this is a result of losing observations as the number of perfect predictions of ownership change by industry dummy variables goes up at finer levels of disaggregation. ${ }^{32}$ Concurrent with these estimated coefficients becoming more negative, however, the sample sizes fall and the standard errors go up. As with the growth results in Table 5, then, the results in Table 6 provide little evidence of market forces that bid away the sex discrimination reflected in the cross-sectional relationship

1987; this had virtually no effect on the results.

${ }^{32}$ When we restricted the sample using the two- or three-digit controls to the observations included in column (3), the estimates were similar to those in column (3). 
between profitability and the percent female for plants with product market power. We emphasize, however, that these results on growth and ownership change are derived from five-year changes, and it is possible that this is not a long enough period of time to be able to measure the effect of competitive market forces on discriminatory practices. ${ }^{33}$

\section{Conclusions}

We find that among plants with high levels of product market power, those that employ relatively more women are more profitable. No such relationship exists for plants with apparently low levels of market power. This is consistent with sex discrimination in wages in the short run in markets where plants have product market power. We also find a positive relationship at the firm level between profitability and the percent of the workforce that is female.

We then turn to evidence on the longer-run effects of market forces on discrimination, asking whether discriminatory employers with market power as evidenced in the cross-sectional results are punished over time through lower growth than non-discriminatory employers, or whether discriminatory employers are bought out by non-discriminators. We find little evidence that this occurs over a five-year period, as growth and ownership change for plants with market power are generally not significantly related to the sex composition of a plant's workforce.

Overall, the results are consistent with the short-run implications of Becker's model of employer discrimination. There is evidence of discrimination in the short run for plants with market power, which indicates that market power may be a prerequisite to the exercise of discriminatory tastes by employers. On the other hand, the evidence does not allow us to reject the hypothesis that market forces do not punish those discriminatory employers with market power in

${ }^{33}$ To put this in perspective, the wage gap between men and women has persisted (although it has narrowed) for decades. Of course, at the level of individual plants or firms market forces may have effects that are manifested more quickly. 
ways that tend to drive them from the market, or at least to shrink them relative to the market. This longer-run evidence is therefore not consistent with the implications of Becker's model for discriminatory employers. Of course, we only have data to try to measure the effect of market forces over a five-year period, and it is quite possible that it takes more time for these market forces to have a measurable effect. Nonetheless, on the basis of this evidence one cannot conclude that market forces tend to eliminate discrimination by punishing discriminatory employers.

Empirical evidence on the role of competitive market forces in eliminating or reducing discrimination-such as that presented in this paper-is critical in assessing government policies to combat discrimination. The direct tools at the government's disposal are equal pay or employment legislation and affirmative action. If market forces reduce or eliminate discrimination, then these direct tools may be unnecessary, and efforts to enhance competition may represent better policies. The results in this paper suggest that product market competition deters discrimination, in that plants and firms with relatively little market power appear not to discriminate, while discrimination only occurs among those plants or firms that are large relative to the market. The evidence also suggests that competitive market forces are unlikely to be sufficient to eliminate discrimination among these large plants or firms. In particular, there is little evidence that, among employers with product market power, longer-run product market competition or competition in the market for ownership acts to undermine or eliminate discrimination. As long as the government is unlikely to enact policies that substantially reduce the product market power of the largest plants or firms, direct government intervention in the labor market may be required if the goal is to reduce discrimination. 


\section{$\underline{\text { References }}$}

Ashenfelter, Orley, and Timothy Hannan. 1986. "Sex Discrimination and Product Market Competition: The Case of the Banking Industry." Quarterly Journal of Economics, Vol. 101, No. 1, February, pp. 149-73.

Becker, Gary S. 1971. The Economics of Discrimination, Second Edition (Chicago: University of Chicago Press).

Blau, Francine D., Marianne A. Ferber, and Anne E. Winkler. 1997. The Economics of Men. Women, and Work, Third Edition (Englewood Cliffs, NJ: Prentice-Hall).

Caballero, Ricardo, John Haltiwanger, and Eduardo Engel. 1995. "Plant-Level Adjustment and Aggregative Investment Dynamics." Brookings Papers on Economic Activity, pp. 1-39.

Domowitz, Ian, R. Glenn Hubbard, and Bruce C. Peterson. 1986. "Business Cycles and the Relationship Between Concentration and Price-Cost Margins." Rand Journal of Economics, Vol. 17, No. 1, Spring, pp. 1-17.

Fuchs, Victor R. 1988. Women's Quest for Economic Equality (Cambridge, MA: Harvard University Press).

Goldberg, Matthew S. 1982. "Discrimination, Nepotism, and Long-Run Wage Differentials." Quarterly Journal of Economics, Vol. 97, No. 2, May, pp. 307-19.

Goldin, Claudia. 1990. Understanding the Gender Gap (New York: Oxford University Press).

Hellerstein, Judith K., and David Neumark. 1995. "Are Earnings Profiles Steeper than Productivity Profiles? Evidence from Israeli Firm-Level Data?" Journal of Human Resources, Vol. 30, No. 1, Winter, pp. 89-112.

Hellerstein, Judith K., David Neumark, and Kenneth R. Troske. 1996. "Wages, Productivity, and Worker Characteristics: Evidence from Plant-Level Production Functions and Wage Equations." NBER Working Paper No. 5626.

Hersch, Joni. 1991. "Equal Employment Opportunity Law and Firm Profitability." Journal of Human Resources, Vol. 26, No. 1, Winter, pp. 139-53.

Lazear, Edward P. 1979. "Why Is There Mandatory Retirement?" Journal of Political Economy, Vol. 87, No. 6, December, pp. 1261-84.

McGuckin, Robert, and George Pascoe. 1988. "The Longitudinal Research Database (LRD): Status and Research Possibilities." Survey of Current Business, November, pp. 30-7.

Neumark, David. 1988. "Employers' Discriminatory Behavior and the Estimation of Wage Discrimination." Journal of Human Resources, Vol. 23, No. 3, Summer, pp. 279-95.

O'Neill, June. 1994. "Discrimination and Income Differences." In Susan F. Feiner, ed. Race and 
Gender in the American Economy (Englewood Cliffs, NJ: Prentice-Hall, Inc.), pp. 13-17.

. 1985. "The Trend in the Male-Female Wage Gap in the United States." Journal of Labor Economics, Vol. 3, No. 1, January, Supplement, pp. S91-S116.

Troske, Kenneth R. 1997. "Evidence on the Employer Size-Wage Premium from WorkerEstablishment Matched Data," mimeo.

Troske, Kenneth R. "The Worker-Establishment Characteristics Database." Forthcoming in John Haltiwanger, Marilyn Manser, and Robert Topel, eds., Labor Statistics Measurement Issues (Chicago: University of Chicago Press). 
Operating

income/sales

(Operating income-

overhead costs)/sales

Percent growth in shipments, 1990-1995

Percent growth in

employment, 1990-1995

Changed ownership, 1990-1995

$\%$ female

$\%$ black

$\%$ married

$\%$ aged $35-54$

$\%$ aged $55+$

$\%$ some college

$\%$ managerial

$\%$ sales

$\%$ craft

Capital/shipments, 1987

Output share in 4-digit

industry, 1987

Birth year of plant

$\mathrm{N}$

\section{Firms, 1987 \\ (2)$$
.238
$$ \\ (.154)}

(.201)

.213

(.206)

$$
\text { ... }
$$$$
\text { (1) }
$$$$
\ldots
$$

ASM, 1989

(3)

.235

(.206)

.219

(.210)

.131

(1.03)

$-.134$

(.472)

.159

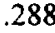

(.226)

.312

.079

(.131)

(.132)

.071

(.135)

$\begin{array}{lc}.841 & .866 \\ (.141) & (.121)\end{array}$

.863
$(.125)$

$(.141)$

.513

.509

.476

(.183)

.137

(.187)

.134

.142

(.123)

(.128)

(.136)

.375

$(.211)$

(.211)

.370
$(.211)$

.158

.156

.155

(.157)

(.155)

.197

(.144)

.201

.197

(.150)

(.143)

.208

(.146)

.201

.207

(.153)

(.144)

.470

.358

.492

(2.23)

(2.53)

(2.41)

.017

$\ldots$

.018

(.036)

1955

(20.6)

$\ldots$

1955

(20.8)

3089

Standard deviations are reported in parentheses. Observations with extreme values of the dependent variables (less than one percent of the sample) are deleted. The variable in the second row is constructed using overhead costs for 1987, since these are available for Census of Manufactures years; it is based on fewer observations. For multi-plant firms in column (2) we aggregate the variables used to construct profits across all establishments in the firm. These data are available only for CM years, along with a separate survey of non-production sites. Data on capital/shipments and output share are also from 1987 (capital and output share are not available for 1989). 


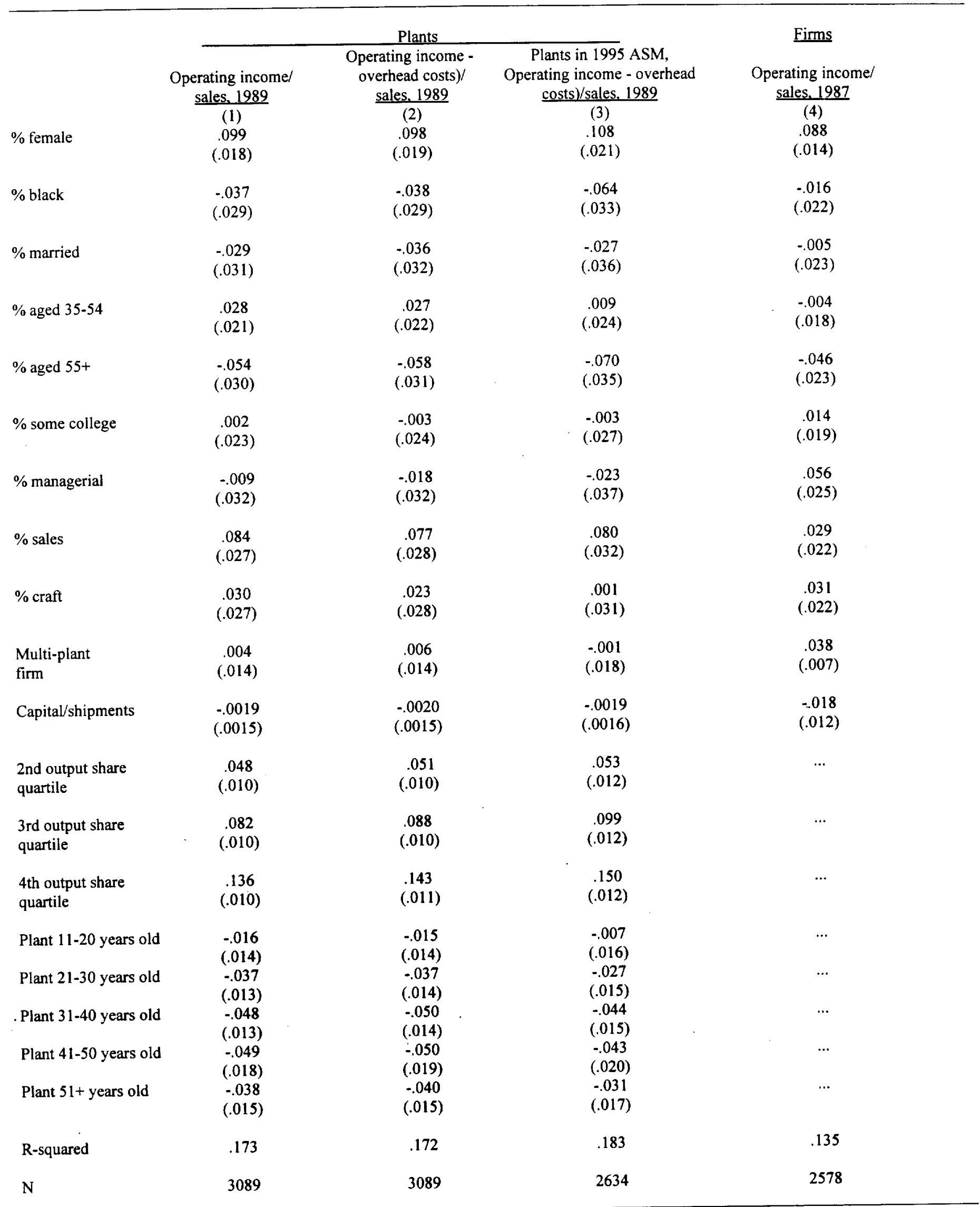

Two-digit industry dummy variables and three Census region dummy variables are also included. Observations with extreme values on the dependent variables (less than one percent of the sample) are deleted. 


\begin{tabular}{|c|c|c|}
\hline$\%$ female & $\begin{array}{c}\text { Three-digit industry controls } \\
(1) \\
.072 \\
(.020)\end{array}$ & $\begin{array}{c}\text { Four-digit industry controls } \\
(2) \\
.046 \\
(.022)\end{array}$ \\
\hline$\%$ black & $\begin{array}{l}-.040 \\
(.029)\end{array}$ & $\begin{array}{l}-.030 \\
(.029)\end{array}$ \\
\hline$\%$ married & $\begin{array}{l}-.028 \\
(.031)\end{array}$ & $\begin{array}{l}-.033 \\
(.032)\end{array}$ \\
\hline$\%$ aged $35-54$ & $\begin{array}{l}.017 \\
(.022)\end{array}$ & $\begin{array}{c}.018 \\
(.022)\end{array}$ \\
\hline$\%$ aged $55+$ & $\begin{array}{l}-.061 \\
(.031)\end{array}$ & $\begin{array}{l}-.065 \\
(.031)\end{array}$ \\
\hline$\%$ some college & $\begin{array}{l}-.017 \\
(.024)\end{array}$ & $\begin{array}{l}-.037 \\
(.024)\end{array}$ \\
\hline$\%$ managerial & $\begin{array}{l}-.047 \\
(.033)\end{array}$ & $\begin{array}{l}-.031 \\
(.034)\end{array}$ \\
\hline$\%$ sales & $\begin{array}{l}.040 \\
(.028)\end{array}$ & $\begin{array}{l}.081 \\
(.029)\end{array}$ \\
\hline$\%$ craft & $\begin{array}{l}.005 \\
(.029)\end{array}$ & $\begin{array}{c}.014 \\
(.030)\end{array}$ \\
\hline $\begin{array}{l}\text { Multi-plant } \\
\text { firm }\end{array}$ & $\begin{array}{l}.003 \\
(.014)\end{array}$ & $\begin{array}{l}-.009 \\
(.014)\end{array}$ \\
\hline Capital/shipments & $\begin{array}{l}-.0023 \\
(.0015)\end{array}$ & $\begin{array}{l}-.0026 \\
(.0015)\end{array}$ \\
\hline $\begin{array}{l}\text { 2nd output share } \\
\text { quartile }\end{array}$ & $\begin{array}{c}.049 \\
(.010)\end{array}$ & $\begin{array}{c}.047 \\
(.011)\end{array}$ \\
\hline $\begin{array}{l}\text { 3rd output share } \\
\text { quartile }\end{array}$ & $\begin{array}{l}.087 \\
(.011)\end{array}$ & $\begin{array}{l}.103 \\
(.012)\end{array}$ \\
\hline $\begin{array}{l}\text { 4th output share } \\
\text { quartile }\end{array}$ & $\begin{array}{l}.142 \\
(.012)\end{array}$ & $\begin{array}{l}.168 \\
(.014)\end{array}$ \\
\hline Plant $11-20$ years old & $\begin{array}{l}-.017 \\
(.014)\end{array}$ & $\begin{array}{l}-.024 \\
(.015)\end{array}$ \\
\hline Plant 21-30 years old & $\begin{array}{l}-.033 \\
(.014)\end{array}$ & $\begin{array}{l}-.039 \\
(.014)\end{array}$ \\
\hline Plant $31-40$ years old & $\begin{array}{l}. .049 \\
(.014)\end{array}$ & $\begin{array}{l}-.055 \\
(.014)\end{array}$ \\
\hline Plant 41-50 years old & $\begin{array}{l}-.043 \\
(.019)\end{array}$ & $\begin{array}{l}-.053 \\
(.019)\end{array}$ \\
\hline Plant $51+$ years old & $\begin{array}{l}-.045 \\
(.015)\end{array}$ & $\begin{array}{l}-.054 \\
(.016)\end{array}$ \\
\hline R-squared & .256 & .370 \\
\hline $\mathrm{N}$ & 3089 & 3089 \\
\hline
\end{tabular}

Dependent variable is (operating income - overhead costs)/sales, as in column (2) of Table 2. Three Census region dummy variables are also included. Observations with extreme values on the dependent variables (less than one percent of the sample) are deleted. See notes to Table 2 for additional details. 
Table 4: Profitability Regressions, Plant Level, Effects of Percent Female at Different Points of Output Share Distribution, and at Different Levels of Industry Detail

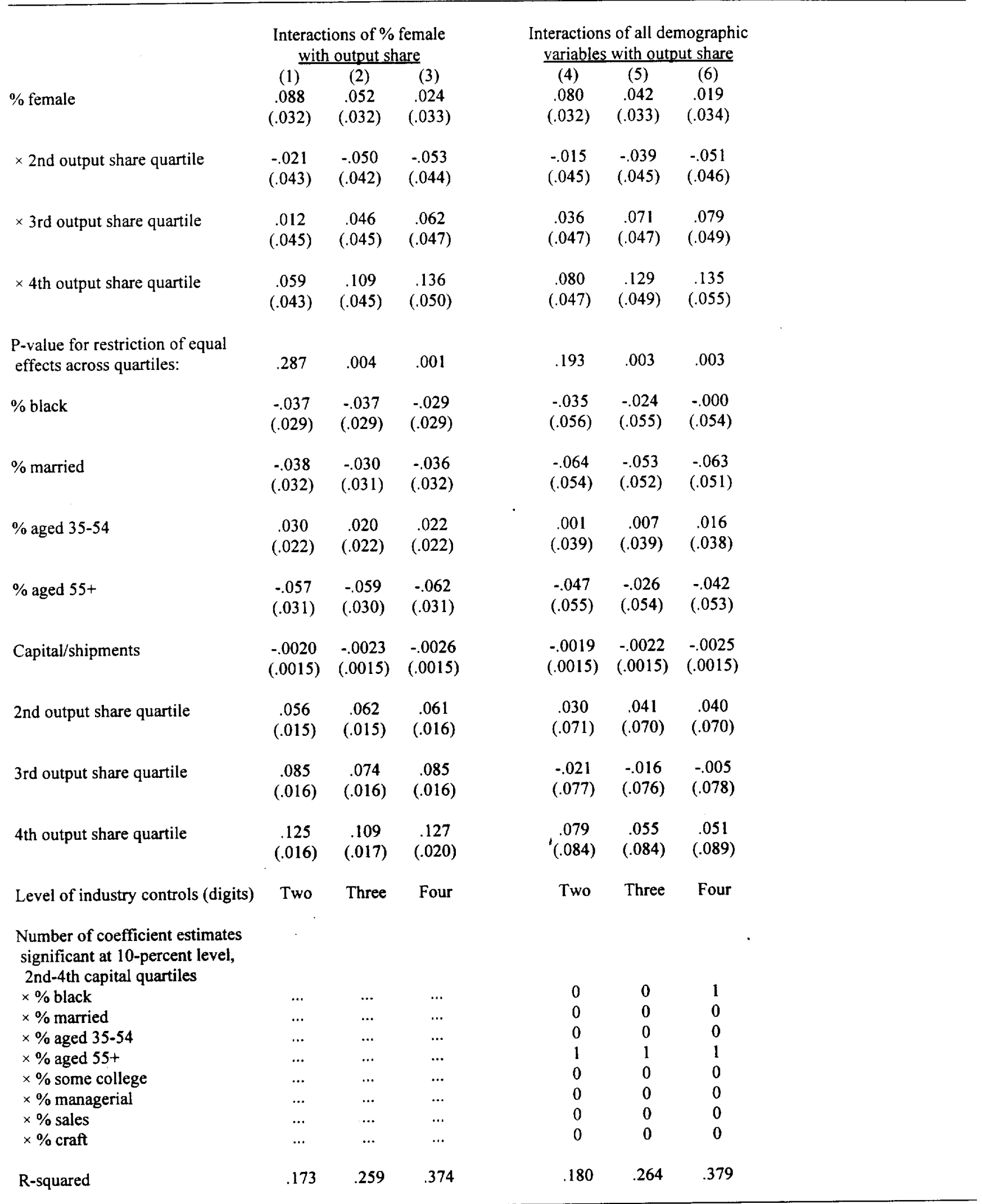

There are 3089 observations. Dependent variable is (operating income - overhead costs)/sales, as in column (2) of Table 2 . Other controls included are: three Census region dummy variables, $\%$ some college, $\%$ managerial, $\%$ sales, $\%$ craft, dummy variables for multi-plant firms and plant age, and dummy variables for two-, three-, or four-digit industries. Observations with extreme values on the dependent variables (less than one percent of the sample) are deleted. Results were the same using operating income/sales. 
Table 5: Shipments and Employment Growth Regressions (1990-1995), Plant Level, Plants Not Changing Ownership, Effects of Percent Female in Fourth Quartile of Output Share Distribution, at Different Levels of Industry Detail

\begin{tabular}{|c|c|c|c|c|c|c|}
\hline & \multicolumn{2}{|c|}{ Two-digit industry controls } & \multicolumn{2}{|c|}{ Three-digit industry controls } & \multicolumn{2}{|c|}{ Four-digit industry controls } \\
\hline & Shipments & Employment & Shipments & Employment & Shipments & Employment \\
\hline \multirow{2}{*}{$\%$ female } & $(1)$ & $(2)$ & (3) & (4) & $(5)$ & $(6)$ \\
\hline & $\begin{array}{l}-.095 \\
(.143)\end{array}$ & -.120 & -.085 & .003 & -.036 & .027 \\
\hline \multirow{2}{*}{$\%$ black } & -460 & 300 & -535 & -386 & -180 & -.044 \\
\hline & $(.221)$ & $(.174)$ & $(.237)$ & $(.188)$ & $(.281)$ & $(.220)$ \\
\hline \multirow[t]{2}{*}{$\%$ married } & .168 & .081 & .029 & -.033 & -.106 & -.033 \\
\hline & $(.269)$ & $(.212)$ & $(.291)$ & $(.231)$ & $(.547)$ & $(.211)$ \\
\hline \multirow[t]{2}{*}{$\%$ aged $35-54$} & -.344 & -.386 & -.434 & -.446 & -.462 & -.426 \\
\hline & $(.167)$ & $(.131)$ & $(.184)$ & $(.146)$ & $(.217)$ & $(.170)$ \\
\hline \multirow[t]{2}{*}{$\%$ aged $55+$} & -.549 & -.395 & -.817 & -.519 & -.826 & -.434 \\
\hline & $(.246)$ & $(.194)$ & $(.282)$ & $(.223)$ & $(.324)$ & $(.253)$ \\
\hline \multirow{2}{*}{$\%$ some college } & .061 & -.012 & -.044 & .032 & -.093 & -.011 \\
\hline & $(.189)$ & $(.149)$ & $(.222)$ & $(.175)$ & $(.261)$ & $(.204)$ \\
\hline \multirow[t]{2}{*}{$\%$ managerial } & -.084 & -.222 & .031 & -.127 & .146 & -.301 \\
\hline & $(.261)$ & $(.205)$ & $(.320)$ & $(.253)$ & $(.367)$ & $(.286)$ \\
\hline \multirow[t]{2}{*}{$\%$ sales } & -.167 & .005 & -.103 & -.046 & -.255 & -.199 \\
\hline & $(.218)$ & $(.172)$ & $(.250)$ & $(.198)$ & $(.315)$ & $(.246)$ \\
\hline \multirow[t]{2}{*}{$\%$ craft } & -.112 & -.290 & -.020 & -.268 & .196 & -.244 \\
\hline & $(.215)$ & $(.169)$ & $(.246)$ & $(.195)$ & $(.299)$ & $(.234)$ \\
\hline \multirow[t]{2}{*}{ Multi-plant firm } & -.200 & -.138 & -.090 & -.035 & -.132 & -.008 \\
\hline & $(.146)$ & $(.115)$ & $(.165)$ & $(.130)$ & $(.183)$ & $(.143)$ \\
\hline \multirow[t]{2}{*}{ Plant $11-20$ years old } & -.063 & .024 & -.115 & -.017 & .017 & .040 \\
\hline & $(.109)$ & $(.086)$ & $(.117)$ & $(.093)$ & $(.131)$ & $(.102)$ \\
\hline Plant 21-30 years old & -.121 & -.022 & -.107 & .012 & $\begin{array}{l}.028 \\
(128)\end{array}$ & $\begin{array}{l}.136 \\
(100)\end{array}$ \\
\hline \multirow{2}{*}{ Plant $31-40$ years old } & $\begin{array}{l}(.103) \\
-.095\end{array}$ & $\begin{array}{l}(.082) \\
-.021\end{array}$ & $\begin{array}{l}(.111) \\
-.069\end{array}$ & $\begin{array}{l}(.088) \\
-.021\end{array}$ & $\begin{array}{l}(.128) \\
.067\end{array}$ & $\begin{array}{l}.100) \\
.064\end{array}$ \\
\hline & $\begin{array}{l}-.095 \\
(.100)\end{array}$ & $\begin{array}{l}-.021 \\
(.079)\end{array}$ & $(.108)$ & $(.086)$ & $(.118)$ & $(.092)$ \\
\hline \multirow[t]{2}{*}{ Plant $41-50$ years old } & -.064 & .013 & -.091 & -.012 & .068 & -.008 \\
\hline & $(.119)$ & $(.093)$ & $(.127)$ & $(.100)$ & $(.143)$ & $(.112)$ \\
\hline \multirow[t]{2}{*}{ Plant $51+$ years old } & -.118 & -.069 & -.157 & -.105 & -.006 & -.050 \\
\hline & $(.105)$ & $(.082)$ & $(.115)$ & $(.091)$ & $(.128)$ & $(.100)$ \\
\hline R-squared & .086 & .104 & .236 & .243 & .518 & .535 \\
\hline
\end{tabular}

There are 605 observations. Two-, three-, or four-digit industry dummy variables and three Census region dummy variables are also included. Observations with extreme values on the dependent variables (less than one percent of the sample) are deleted. 
Table 6: Change in Ownership Probits (1990-1995), Plant Level, Effects of Percent Female in Fourth Quartile of Output Share Distribution, and at Different Levels of Industry Detail

\begin{tabular}{|c|c|c|c|}
\hline$\%$ female & $\begin{array}{c}\text { Two-digit industry controls } \\
(1) \\
-.105 \\
(.082)\end{array}$ & $\begin{array}{c}\text { Three-digit industry controls } \\
(2) \\
-.143 \\
(.115)\end{array}$ & $\begin{array}{c}\text { Four-digit industry controls } \\
(3) \\
-.203 \\
(.240)\end{array}$ \\
\hline$\%$ black & $\begin{array}{l}-.127 \\
(.128)\end{array}$ & $\begin{array}{l}-.185 \\
(.159)\end{array}$ & $\begin{array}{l}-.048 \\
(.302)\end{array}$ \\
\hline$\%$ married & $\begin{array}{l}.199 \\
(.169)\end{array}$ & $\begin{array}{l}.128 \\
(.217)\end{array}$ & $\begin{array}{c}.376 \\
(.442)\end{array}$ \\
\hline$\%$ some college & $\begin{array}{l}-.145 \\
(.112)\end{array}$ & $\begin{array}{l}-.236 \\
(.153)\end{array}$ & $\begin{array}{l}-.592 \\
(.323)\end{array}$ \\
\hline$\%$ managerial & $\begin{array}{l}-.049 \\
(.159)\end{array}$ & $\begin{array}{l}-.235 \\
(.228)\end{array}$ & $\begin{array}{l}-.160 \\
(.450)\end{array}$ \\
\hline$\%$ sales & $\begin{array}{c}.046 \\
(.132)\end{array}$ & $\begin{array}{l}-.072 \\
(.175)\end{array}$ & $\begin{array}{l}-.283 \\
(.376)\end{array}$ \\
\hline$\%$ craft & $\begin{array}{l}.036 \\
(.117)\end{array}$ & $\begin{array}{l}-.008 \\
(.162)\end{array}$ & $\begin{array}{c}.049 \\
(.324)\end{array}$ \\
\hline Multi-plant firm & $\begin{array}{l}-.140 \\
(.093)\end{array}$ & $\begin{array}{l}-.087 \\
(.113)\end{array}$ & $\begin{array}{l}-.115 \\
(.192)\end{array}$ \\
\hline Plant $11-20$ years old & -.031 & $\begin{array}{l}-.037 \\
(.078)\end{array}$ & $\begin{array}{l}-.094 \\
(.158)\end{array}$ \\
\hline Plant $21-30$ years old & $\begin{array}{l}.053 \\
(.073)\end{array}$ & $\begin{array}{l}.054 \\
(.089)\end{array}$ & $\begin{array}{l}.040 \\
(.180)\end{array}$ \\
\hline Plant $31-40$ years old & $\begin{array}{l}.048 \\
(.067)\end{array}$ & $\begin{array}{l}.043 \\
(.082)\end{array}$ & $\begin{array}{l}.038 \\
(.171)\end{array}$ \\
\hline Plant 41-50 years old & $\begin{array}{l}-.014 \\
(.072)\end{array}$ & $\begin{array}{l}-.005 \\
(.091)\end{array}$ & $\begin{array}{l}-.081 \\
(.169)\end{array}$ \\
\hline Plant $51+$ years old & $\begin{array}{c}.074 \\
(.075)\end{array}$ & $\begin{array}{c}.054 \\
(.089)\end{array}$ & $\begin{array}{c}.096 \\
(.179)\end{array}$ \\
\hline Pseudo R-squared & .056 & .107 & .140 \\
\hline $\mathrm{N}$ & 743 & 611 & 319 \\
\hline
\end{tabular}

Partial derivatives of the probability of a change in ownership with respect to each variable are reported; standard errors are rescaled to match t-

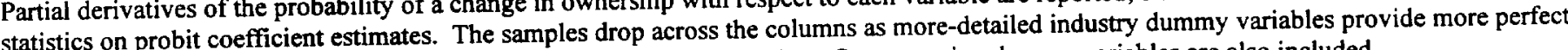
predictions. Two-, three-, or four-digit industry dummy variables and three Census region dummy variables are also included. 